CATALLAXY

Volume 4 Issue 1 June 2019

e-ISSN 2544-090X

¿ www.catallaxy.pl

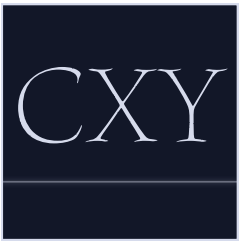

Oryginalny artykut naukowy

otrzymano: 04.06.2019 / zaakceptowano: 20.06.2019 / opublikowano online: 30.06 .2019

Wachowiak, A., i Kowalczyk, K. (2019). Dobrobyt społeczny w świetle ekonomii szczęścia na przykładzie wybranych państw Unii Europejskiej. Catallaxy. 4(1): 45-55. doi:10.24136/cxy.2019.003.

\title{
Dobrobyt społeczny w świetle ekonomii szczęścia na przykładzie wybranych państw Unii Europejskiej
}

\section{ARTUR WACHOWIAK}

autor korespondencyjny

Uniwersytet Ekonomiczny w Poznaniu, al. Niepodległości 10, 61-875 Poznań, Polska

\wachowiak.artur@gmail.com

(iD) orcid.org/0000-0001-6587-2406

\section{KAMIL KOWALCZYK}

Uniwersytet Ekonomiczny w Poznaniu, Polska

$\square$ kamil.kowalczyk.5109@gmail.com

(iD) orcid.org/0000-0003-3057-3005

\begin{abstract}
Abstrakt
Motywacja: Jednym z podstawowych problemów makroekonomii jest kwestia dobrobytu społeczeństw. W przeszłości, znacząca część ekonomistów zwykła utożsamiać wielkość gospodarki, bądź dynamikę jej wzrostu, ze stopą życiową. Obecnie, ocena dobrobytu społeczeństwa sprowadza się do oceny jakości życia w danym państwie. W głównym nurcie rozważań makroekonomicznych przyjęło się posługiwanie miarą jaką jest Produkt Krajowy Brutto (PKB) wraz z jej pochodnymi. Niestety wskaźniki te nie obejmują wielu kluczowych czynników wpływających na poziom dobrobytu. Z tego powodu na przestrzeni lat zastosowano nowe, szersze podejście i opracowano nowe mierniki takie, jak np. Wskaźnik Rozwoju Społecznego (Human Development Index, HDI). Koniecznym wydaje się rozważenie ich wartości poznawczej w kontekście współczesnego dorobku ekonomii szczęścia. W tym celu dokonano przeglądu najpopularniejszych wskaźników dobrobytu i jakości życia oraz skonfrontowano je z pozaekonomicznymi danymi opisującymi procesy zachodzące w społeczeństwach, zwracając szczególną uwagę na różnice interpretacyjne i możliwe odmienne oceny. Cel: Celem jest ocena pomiaru jakości stopy życiowej, przez przegląd dostępnych rozwiązań i metod oraz konfrontacja wyników z danymi publicznych statystyk wybranych panstw Unii Europejskiej (UE).

Materiały i metody: Wykorzystano przegląd systematyczny i analizę krytyczną literatury, analiza zagregowanych danych makroekonomicznych oraz statystyki publicznej. Material empiryczny stanowią dane publikowane przez Eurostat, Organizację Współpracy Gospodarczej i Rozwoju (Organisation for Economic Co-operation and Development, OECD), Światową Organizację Zdrowia (World Health Organization, WHO) oraz Bank Światowy (World Bank).

Wyniki: Istnieją istotne różnice w ocenie jakości życia między wskaźnikami przyjętymi w głównym dyskursie ekonomicznym a empirycznymi danymi z innych nauk, tj. spolecznych czy medycznych.
\end{abstract}

Stowa kluczowe: dobrobyt; szczęście; zadowolenie; makroekonomia

JEL: E19; F59; B52 


\section{Wprowadzenie}

Refleksja nad dobrobytem towarzyszy ludzkości od czasów starożytnych. Początkowo, analiza jego istoty była domeną filozofów, którzy, jak przykładowo Arystoteles (2007), utożsamiali go z szczęściem. Później, w wyniku narastających zawiłości realiów społeczno-gospodarczych i ukształtowania się nauk ekonomicznych, zagadnienie to stało się obiektem zainteresowania większości szkół ekonomii. Obecnie, pojęcie dobrobytu nadal wzbudza zainteresowanie naukowców. Jedną z przyczyn takiego stanu rzeczy jest mnogość interpretacji tego pojęcia. Powszechnie przyjmuje się, że składa się ono $z$ zaspokojenia potrzeb zarówno materialnych, jak i duchowym jednostki czy społeczeństwa (Tatarkiewicz, 2008).

W stwierdzeniu tym można spostrzec swoisty dualizm, który dotyczy dwóch skrajnych płaszczyzn. Pierwsza z nich - fizyczna, możliwa jest do wyrażenia w pieniądzu, jak np. wartość posiadanych aktywów lub bogactw. $Z$ kolei druga, dotyczy zaspokojenia potrzeb duchowych, jak np. poczucia sprawiedliwości, przynależności, estetyki. Ta część definicji, $z$ uwagi na jej pozornie niemierzalny charakter, do dziś jest przedmiotem sporów między ekonomistami odnośnie wiarygodności i celowości uwzględniania czy interpretacji otrzymywanych wyników.

Pomiar bogactwa społeczeństw wydaje się jednym $z$ istotniejszych problemów współczesnej teorii ekonomii. Kluczowa jest także ocena otrzymanych wyników. Istotne są odpowiedzi na pytania o to, czy powinno traktować się poziom dobrobytu jako kolejny parametr opisujący gospodarkę, czy też jako jedną $z$ wartości, która powinna być maksymalizowana polityką państwa. Częściową odpowiedź na kolejne pytanie o sens powiększania dobrobyty dostarcza filozofia. W przypadku tej nauki, szczęście stawiane jest jako jedna $z$ wartości uwarunkowana dobrobytem (Kanasz, 2015).

Celem jest ocena pomiaru jakości stopy życiowej, przez przegląd dostępnych rozwiązań i metod oraz konfrontacja wyników $z$ danymi publicznych statystyk wybranych państw Unii Europejskiej (UE).

W sekcji 2. przedstawiono przegląd literatury przedmiotu. W sekcji 3. scharakteryzowano mierniki oparte na Systemie Rachunków Narodowych. W sekcji 4. zaprezentowano niestandardowe mierniki dobrobytu. W sekcji 5. opisano wykorzystane materiały i metody. W sekcji 6. przedstawiono otrzymane wyniki, natomiast $\mathrm{w}$ sekcji 7. zawarto podsumowanie przeprowadzonej analizy.

\section{Przegląd literatury}

Jednym $z$ przedmiotów zainteresowania ekonomii klasycznej jest dobrobyt. Już A. Smith (2015) analizował przyczyny bogactwa narodów. Na koniec XVIII wieku J. Bentham przedstawił zasadę największego szczęścia, którą można sprowadzić do dążenia do największego dobra, w jak największej ilości, przy minimalizacji tego, co nieprzyjemne. Warto zwrócić uwagę na fakt, że kategorie takie, jak „dobrobyt”, „bogactwo", „szczęście”, „przyjemność" były używane jako synonimy (Włodarczyk, 2014). Kolejni ekonomiści rozwijający teorię mikroekonomii wprowadzili pojęcie użyteczności. Definiowane jest ono jako właściwość dobra, które prowadzi do korzyści, pożytku, przyjemności lub chroni przed zdarzeniami takimi, jak powstanie szkody, uszczerbku czy przykrości. Wprost do niej nawiązuje mikroekonomiczne I prawo Gossena, znane jako prawo malejącej użyteczności krańcowej. Zgodnie z nim, zadowolenie z pierwszej jednostki konsumowanego dobra jest większe niż z kolejnych jednostek. W rezultacie przyrosty zadowolenia $z$ konsumpcji, mierzone jako użyteczność marginalna, zmniejszają się wraz ze wzrostem konsumowanego dobra. Determinuje to istnienie pewnego poziomu optymalnej konsumpcji, dla której całkowite zadowolenie jest maksymalne, a krańcowa użyteczność równa zeru, zaś kolejne zużywane jednostki powodują spadek satysfakcji konsumenta. Innym podejściem, w ramach teorii zachowania konsumenta, jest koncepcja wyboru optymalnego poziomu konsumpcji, związana z krzywą preferencji i linią ogra- 
niczenia budżetowego. Konsument dąży do maksymalizacji konsumpcji przy ograniczeniu budżetowym, a przy wzroście dochodu osiąga kolejne poziomy konsumpcji, które wiążą się z wyższym poziomem zadowolenia (Rekowski, 2015). Sposób postrzegania użyteczności zmienil się za sprawą Vi. Pareto, który przyjął, że na poziom satysfakcji wpływ ma wybór między różnymi możliwościami, a użyteczność nie musi oznaczać koniecznie dążenia do szczęścia (Michoń, 2010).

W drugiej połowie XX wieku zaczęła rozwijać się nowa gałąź ekonomii zajmująca się badaniem szczęścia w ujęciu szerszym niż psychologiczne, filozoficzne i socjologiczne. Początkowo, zapożyczono siatkę pojęciową i założenia $z$ nauk społecznych i humanistycznych dostosowując ją na potrzeby rozważań ekonomicznych. Wykorzystywano $\mathrm{w}$ ten sposób wskaźniki ogólnego dobrostanu do pomiaru użyteczności pieniędzy. Jednak nadal najpopularniejszą metodą analizy poziomu dobrobytu było obliczanie i porównywanie wartości PKB per capita między poszczególnymi gospodarkami. Metoda ta daje jedynie powierzchowne wyniki, gdyż nie bierze się pod uwagę bezpośrednio wszystkich czynników społecznych takich, jak: średnia długość życia, stopa bezrobocia, ilość wolnego czasu, poziom wykształcenia, skala występowania uzależnień, itp. (Czapiński, 2012). Wymienione zjawiska odnoszą się do zdarzeń i warunków występujących w zbiorowościach, dotykają również pojedynczych jednostek. W związku z tym, należałoby rozdzielić pojęcie dobrobytu na dobrobyt ekonomiczny, związany stricte $z$ wartościami mierzalnymi oraz dobrobyt społeczny inklinujący podejście od strony zdarzeń natury ogólnospołecznej. Uwagi te podsumował laureat Nagrody Nobla S. Kuznets stwierdzając w 1934 roku, że „dobro narodu może mieć słaby związek $z$ dochodem narodowym" (Cobb i in., 1995).

Sformułowanie to, wówczas całkiem zagadkowe, zaczęło nabierać na znaczeniu dopiero $\mathrm{w}$ latach 60 . XX wieku w wyniku zauważalnych, negatywnych efektów zewnętrznych wzrostu gospodarczego - zanieczyszczeń środowiska. Zjawiskiem tym zainteresował się również amerykański ekonomista R. Easterlin (1974, ss. 89-125), który jako pierwszy podjął się opracowania danych dotyczących wpływu bogactwa na szczęście. Przeprowadził on badanie ankietowe wśród mieszkańców Stanów Zjednoczonych odnośnie ich poczucia szczęścia. Analizując dane $z$ lat 1946-1970 stwierdzil, ze widoczny wzrost gospodarczy, tj. dochodu per capita, nie łączy się z uczuciem zadowolenia wśród Amerykanów. Począwszy od lat 60. XX wieku Amerykanie zaczęli sukcesywnie odczuwać mniejszy stopień satysfakcji, a więc przypuszczalnie ich poczucie szczęścia zaczęło maleć. W celu weryfikacji swoich wyników, R. Easterlin (1995, ss. 35-47) przeprowadzil podobne badania $w$ innych rozwiniętych państwach. Wyniki okazały się być jednoznaczne - potwierdzono zjawisko, które zdaje się być oczywiste: wraz ze wzrostem dochodu, jednostki są skłonne bardziej odczuwać szczęście. Jednak w przypadku analizy danych międzynarodowych, założenie to przestało być tak intuicyjne. $\mathrm{Na}$ poziomie makroekonomicznym można dostrzec, że po osiągnięciu określonego poziomu PKB per capita, średni subiektywny dobrostan członków społeczeństwa przestaje istotnie wzrastać. Zjawisko to zaczęto określać jako paradoks Easterlina.

W ślad za tym, ekonomiści zaczęli poszerzać dotychczasowe spektrum badań, niejako wracając do ekonomii jako nauki stricte społecznej, jednocześnie odwołując się psychologii i filozofii i formułując nowe koncepcje teoretyczne.

W tabeli 1. przedstawiono determinanty szczęścia według różnych podejść w ekonomii szczęścia. Różnice w postrzeganiu koncepcji szczęścia i wspólne rozważania przyczyniły się do przeprowadzania kolejnych badań interdyscyplinarnych, których przedmiotem było ustalenie zależności między bogactwem a szczęściem oraz innymi przejawami życia społecznego. Można stwierdzić, że osiągnięto konsensus co do następujących twierdzeń (Włodarczyk, 2014):

- poczucie szczęścia zależy od dochodu, który determinuje wielkość konsumpcji, 
lecz poziom szczęścia kształtują także inne czynniki, $w$ tym pozaekonomiczne;

- istotnym determinantem szczęścia jednostki jest stosunek jej dochodu do dochodu innych jednostek: im większe względne różnice, tym częściej obserwowany jest spadek szczęścia jednostek lub grup społecznych;

- bezrobocie silnie wpływa na spadek szczęścia;

- jednostki zakładają, że w przyszłości ich szczęście będzie rosło, gdyż przeceniają oddziaływanie rosnącej bieżącej konsumpcji na przyszły poziom własnej satysfakcji;

- mieszkańcy państw bogatszych są szczęśliwsi, jednak istnieje taki poziom dochodu, powyżej którego dalszy jego wzrost ma niewielki wpływ na zwiększenie zadowolenia (paradoks Easterlina).

Jako polski wkład do ekonomii szczęścia (economy of happiness), warto przybliżyć koncepcję socjologa J. Czapińskiego, który w 1989 roku przedstawił tzw. cebulową teorię szczęścia, należącą do teorii stałego potencjału szczęścia. Zgodnie z nią, dobrostan zależy od warunkowanej genetycznie stałej woli życia i zmiennych aspektów zadowolenia cząstkowego, wraz z czynnikami kontekstowymi, jak np. kultura.

Dobrostan dzieli się na trzy warstwy:

- wolę życia - jako warstwa trwała, wewnętrzna (rdzeń) jest warunkowana genetycznie i występuje we wszystkich organizmach żywych (obiektywna);

- ogólny dobrostan psychiczny - warstwa umiarkowanie zależna od obiektywnych zmian w środowisku, związana z subiektywną oceną rzeczywistości;

- zadowolenie $z$ poszczególnych dziedzin życia - najbardziej zewnętrzna warstwa, wrażliwa na bieżącą sytuację w życiu prywatnym, zawodowym, stan zdrowia, jest zależna od procesu socjalizacji, przekonań i innych czynników społecznych.

W perspektywie długoterminowej, potencjał ogólnego subiektywnego szczęścia jest ograniczany poziomem woli życia, jednak może być także nieosiągany. Do momentu zaspokojenia podstawowych potrzeb jednostki, poziom szczęścia reaguje na warunki bytowe. Natomiast po przekroczeniu tego progu dochodu, staje się on zasobem, który zwiększa możliwość osiągania większych dochodów (oddziaływanie ma kierunek odwrotny). Na poziomie makroekonomicznym, konieczne jest także wytworzenie przez społeczeństwo tzw. kapitału społecznego (Czapiński, 2005).

Mimo tego, ekonomiści zajmujący się ekonomią szczęścia, próbują w swoich dociekaniach stworzyć miarę podchodzącą do problematyki dobrobytu wielowymiarowo, kreując mierniki syntetyczne nawiązujące do nauk psychologicznych czy socjologicznych. Różnice w definicji i percepcji szczęścia mogą powodować wiele niejasności, dlatego na potrzeby dalszej analizy, przyjęto szczęście jako stan zadowolenia i usatysfakcjonowania jednostek w zbiorowości społeczeństwa.

\section{Miary oparte na Systemie Rachunków Narodowych}

$\mathrm{Na}$ schemacie 1. przedstawiono podział mierników ekonomicznych. Obecnie, na potrzeby pomiaru wielkości gospodarki i jej potencjału, przyjęło się używać $\mathrm{w}$ statystyce publicznej miar opartych na Systemie Rachunków Narodowych. System ten można określić jako uporządkowany zbiór spójnych i logicznie połączonych rachunków ekonomicznych, bilansów oraz innych narzędzi, stworzonych w celu pomiaru efektów działań ekonomicznych i przedstawienia pełnego (na ile to możliwe) obrazu gospodarki narodowej (Cieślik, 2008, s. 148).

Podstawowym i najpowszechniej przyjętym wskaźnikiem kondycji gospodarki jest zaproponowany przez S. Kuznetsa indeks Produkt Krajowy Brutto, PKB (Gross Domestic Product, GDP) (Nordhaus i Tobin, 1972). Jest to miara wielkości produkcji wytworzonej na terenie danego państwa w określonym czasie, bez względu na to, kto jest właścicielem czynników produkcji. Pomiaru można dokonać w różny sposób, tj. poprzez sumo- 
wanie dochodów, wydatków lub wartości produktów. Wskaźnik ten może być podawany w cenach rynkowych i w cenach czynników produkcji, zależnie od tego czy uwzględniono podatki pośrednie i subsydia. Odmienną perspektywę przyjęto formułując Produkt $\mathrm{Na}$ rodowy Brutto, PNB (Gross National Product, GNP) biorący pod uwagę aspekt obywatelstwa właścicieli czynników wytwórczych (Barro, 1997). Możliwe jest także ukazanie wartości netto tych wskaźników po korekcie o wartość amortyzacji.

Warto zauważyć, że przedstawione mierniki odnoszą się wszystkich uczestników rynku. W celu zobrazowania sytuacji ekonomicznej gospodarstw domowych (mieszkańców), konieczne wydaje się pomniejszenie Produktu Narodowego Netto (PNN), czyli tzw. Dochodu Narodowego (DN), o podatki bezpośrednie, płacone przez przedsiębiorstwa oraz zyski niepodzielone. Otrzymaną wielkość definiuje się jako dochody osobiste. Korygując tą wielkość o podatki bezpośrednie, płacone przez gospodarstwa domowe i o płatności transferowe, można uzyskać poziom rozporządzalnego dochodu osobistego, czyli ilość środków pieniężnych, którą gospodarstwa domowe moga przeznaczyć na konsumpcję lub oszczędności.

W celu określenia bogactwa społeczeństwa, niezbędnym jest odniesienie uzyskanych wielkości produktu i dochodu narodowego do populacji państwa. Wartości per capita dokładniej opisują dobrobyt przypadający na jednego mieszkańca. Należy pamiętać, że tradycyjne mierniki gospodarcze posiadają liczne wady. Głównym mankamentem tej grupy wskaźników jest nieuwzględnianie efektów pracy, które nie znajdowały się $\mathrm{w}$ obiegu rynkowym (produkty i usługi wykonywane na własne potrzeby w gospodarstwach domowych) oraz szarej strefy. Dodatkowo, pomija się także działanie efektów zewnętrznych i rynków finansowych. Dużo wątpliwości wzbudza także zaliczanie do wskaźnika tzw. antydóbr, czyli towarów lub usług szkodzących użytkownikom, np. alkohol, papierosy, itp. (Krugman i Wells, 2012).
Wady ujęcia tradycyjnego skłoniły ekonomistów do modyfikacji rachunków narodowych przez uwzględnienie jakościowych płaszczyzn dobrobytu. Takie podejście cechuje koncentracja nie tylko na indywidualnym zaspokajaniu potrzeb poszczególnych podmiotów gospodarczych, ale również na potrzebach społecznych. Można wyróżnić cztery najważniejsze wskaźniki.

Pierwszym z nich jest Miernik Dobrobytu Ekonomicznego (Measure of Economic Wealth, MEW), stworzony przez W. Nordhausa i J.Tobina (1972). Uwzględnia on konsumpcję prywatną i rządową, dobra wytwarzane w gospodarstwach domowych, wartość wolnego czasu oraz wydatki na ochronę środowiska i szkody wynikające z jego degradacji. Wskaźnik ten służy do szacowania pieniężnego poziomu dobrobytu.

Istnieje także zbliżony konstrukcyjnie wskaźnik, tj. Miernik Czystego Dobrobytu (Net National Welfare, NNW). Rozbieżności między nimi wynikają z różnego ujęcia wydatków na edukację i wyceny czas wolnego.

Trzecim jest Wskaźnik Ekonomicznych Aspektów Dobrobytu (Economic Aspects of Welfare, EAW), opracowany przez X. Zolotasa. W jego przypadku uwzględniono szerokie spektrum czynników jakościowych takich, jak: czas wolny, sektor usług publicznych, wydatki na dobra trwałego użytku, wydatki prywatne na ochronę zdrowia oraz wydatki na konsumpcję prywatną po dokonaniu korekt o szereg kosztów, np. związanych z zanieczyszczeniem środowiska naturalnego.

Czwartym jest Indeks Trwałego Dobrobytu Ekonomicznego (Index of Sustainable Economic Welfare, ISEW), opracowany przez H. Dalyego i J. Cobba. Oparto go na indywidualnych wydatkach konsumpcyjnych, pomniejszonych o straty wynikające $z$ nierównej dystrybucji dochodu, kosztów wyeksploatowanych zasobów i degradacji środowiska naturalnego oraz innych wydatków.

Należy pamiętać, że wskaźniki te posiadają pewne wady. Większość z nich oparta jest na składowych $\mathrm{PKB}$, faworyzując w ten sposób czynniki materialne. Konstrukcja teoretyczna nie uwzględnia wszystkich faktorów jakościo- 
wych lub uwzględnia je wybiórczo. Istnieją także liczne problemy metodologiczne w ustalaniu roli danego czynnika i jego wpływu na jakość życia mieszkańców. Trudnym wydaje się także opracowanie narzędzi pomiaru czynników społecznych czy ekologicznych. W przypadku płaszczyzny ogólnospołecznej, kontrowersje stanowi identyfikacja zjawisk istotnych i sposób ich opisu ilościowego oraz wiarygodność samego pomiaru. Natomiast w przypadku sfery ekologicznej, wątpliwości dotyczą wyboru między miarami fizycznymi (np. zanieczyszczenie $\mathrm{w} \mathrm{mg} / \mathrm{m}^{3}$ powietrza) a ekonomicznymi (np. nakłady na rekultywacje zanieczyszczonych terenów w PLN) (Milewski i Kwiatkowski, 2005).

\section{Niestandardowe mierniki dobrobytu}

$Z$ czasem standardowe mierniki dobrobytu zaczęły okazywać się niewystarczające, a ekonomiści zaczęli poszukiwać podejścia wielowymiarowego, skupiającego się zarówno na pomiarze jakości życia mieszkańców, jak $\mathrm{i}$ jego poziomie $\mathrm{w}$ ujęciu zrównoważonego rozwoju. Osobliwość poziomu dobrobytu nie musi oznaczać wysokich dochodów czy dużego bogactwa. Jak wskazuje paradoks Easterlina, szczęście nie zawsze łączy się $z$ bogactwem materialnym. W związku z tym, na gruncie praktyki badawczej, wypracowano miary indeksowe podchodzące alternatywnie do pomiaru poziomu dobrobytu.

Do nowoczesnych miar należy Wskaźnik Rozwoju Społecznego (Human Development Index, HDI). Jest to obecnie najpopularniejszy indykator rozwoju społeczno-ekonomicznego, opublikowany po raz pierwszy w 1990 roku przez Program Narodów Zjednoczonych ds. Rozwoju (United Nations Development Programme, UNDP). Zawiera on trzy agregaty: długość i zdrowe życie, wiedza (jako ogólny wskaźnik skolaryzacji brutto dla średnich i spodziewanych lat nauczania) oraz poziom PNN per capita. Za pomocą tego wskaźnika uproszczono i przedstawiono jedynie skutki ludzkiego rozwoju, nie skupiając się na bezpieczeństwie, zadowoleniu czy nierównościach.
Kolejnym indeksem jest Światowy Wskaźnik Szczęścia (Happy Planet Index, HPI) opracowany przez National Economic Foundation (NEF) i przestawiający sposób, w jaki narody wykorzystują zasoby środowiska naturalnego do szczęśliwego życia. Indykator łączy cztery elementy:

- dobrobyt postrzegany przez mieszkańców danego państwa w skali od jednego do dziesięciu; dane służące do pomiaru dobrobytu częściowo pochodzą z Gallup World Poll (Gallup Analytics, 2018);

- spodziewaną długość życia w danym państwie, liczoną na podstawie danych Organizacji Narodów Zjednoczonych, ONZ (United Nations, UN);

- nierówności dochodowe, liczone w aspekcie długości życia i poczucia zadowolenia, bazują na ilości spodziewanej długości życia oraz danych dotyczących dobrobytu, są wyrażane w procentach;

- ślad środowiskowy, rozumiany jako średni wpływ, jaki każdy rezydent danego państwa ma na środowisko; dane używane do pomiaru tej kategorii pochodzą z Global Footprint Network i wyrażane są w globalnych hektarach na osobę (gha).

Następnym indeksem jest Indeks Lepszego Życia (Better Life Index, BLI), użyty po raz pierwszy w 2011 roku przez Organizację Współpracy Gospodarczej i Rozwoju (Organisation for Economic Co-operation and Development, OECD) w celu międzynarodowego porównania poziomu dobrobytu w gospodarkach rozwiniętych. Miarę tę stworzyła Komisji ds. Wydajności Ekonomicznej i Postępu Społecznego, w której skład wchodził J.E. Stiglitz i in. (2009). Wskaźnik składa się z jedenastu „wymiarów” dobrobytu takich, jak: dochód, jakość środowiska, praca, bezpieczeństwo, zdrowie, satysfakcja z życia.

Ostatnim jest Indeks Jakości Życia ( $Q u$ ality of Life Index, $\mathrm{QoL}$ ), opracowany przez Eurostat biorący pod uwagę dziewięć dziedzin zdefiniowanych jako nadrzędne przy pomiarze dobrobytu społecznego. Uwzględniono w nim materialne warunki życia (dochód, konsumpcja, warunki materialne), zatrudnienie, edukację, zdrowie, czas wolny, interakcje 
społeczne, ekonomiczne i fizyczne, bezpieczeństwo, zarządzanie, podstawowe prawa, naturalne środowisko i ogólną jakość życia.

Wymienione wskaźniki nie mogą i nie powinny eliminować miar tradycyjnych. Jak wykazał laureat Nagrody Nobla D. Kahneman - ludzie, oceniając swoje poczucie dobrostanu na przestrzeni czasu, będą udzielać innych odpowiedzi niż gdyby zmierzono całe społeczeństwo „teraz” (Kahneman i Sugden, 2005). Można się zgodzić $z$ tym stwierdzeniem, ponieważ ludzie mają problem $z$ pomiarem własnego szczęścia i szybko adaptują się do nowych sytuacji, co powoduje zakrzywienie ich przyszłych, potencjalnych ocen. $Z$ drugiej strony, dokonywanie szacunków ksztaltowania się tych wskaźników powinno sprzyjać racjonalizacji polityki społeczno-gospodarczej, jak i rozwoju ekonomii, w kontekście analizy poziomu szczęścia.

\section{Materiały i metody}

W celu oceny analizowanej relacji, zastosowano analizę korelacji między wybranymi miarami dobrobytu a szeroko rozumianymi przejawami szczęścia społeczeństw.

Indykatory opisujące poziom stopy życiowej są konstruowane przy zaangażowaniu różnych zmiennych o charakterze jakościowym i ilościowym. W celu oceny ich wartości poznawczej, dokonano analizy korelacji między wybranymi wskaźnikami a częstotliwością występowania wybranych (pozytywnych i negatywnych) zjawisk ogólnospołecznych.

Za zbiorowość statystyczną uznano państwa UE. Wybór ten motywowany jest faktem, że mimo różnic $\mathrm{w}$ poziomie i dynamice wzrostu gospodarczego, państwa te wykazują wyraźne analogie w przypadku instytucjonalnych rozwiązań społecznej gospodarki rynkowej. Należy wskazać także na podobieństwa kulturowe wywodzące się $z$ dorobku cywilizacji antyku i chrześcijaństwa, a także rozwiązania polityczne będące wyrazem, w całości lub częściowo, realizacji wartości współczesnej demokracji liberalnej. Czyni to państwa UE relatywnie jednorodną grupą $w$ porównaniu do państw innych regionów świata, np. państw azjatyckich.

W celu przeprowadzenia ewaluacji, obliczono poziom wskaźnika korelacji Pearsona dla danych dotyczących z 2016 roku. Wyjątek stanowily dane odnoszące się do odsetka samobójstw nastolatków, które pochodziły z 2015 roku. Analizowane zależności dotyczyły dwóch grup danych. Pierwszą z nich stanowiły wyniki badań ogólnospołecznych zjawisk i opinii takich, jak:

- całkowita satysfakcja z życia;

- ocena wartości życia;

- ocena własnego stanu zdrowia;

- liczba samobójstw wśród nastolatków w wieku 15-19 lat na 100 tys. mieszkańców;

- ocena obecnej satysfakcji w skali od jednego do dziesięciu;

- liczba chorób związanych $z$ nadużywaniem alkoholu i narkotyków w procentach populacji.

Zjawiska te wybrano ze względu na ich przekrojowość oceny ludzkiego szczęścia. Pierwsza zmienna odnosiła się do bezpośredniego pytania o odczuwaną satysfakcję subiektywną $w$ danym momencie. Druga zmienna dotyczyła etyczno-egzystencjonalnego wartościowania życia w oparciu o przemyślenia i doświadczenia respondentów. Kolejną zmienną była subiektywna ocena własnego stanu zdrowia. Poziom stopy życiowej i dobrostanu organizmów przejawia się m.in. przez odpowiedni przebieg procesów życiowych składających się na pojęcie zdrowia fizycznego. Kolejne czynniki odnosiły się do niepożądanych zjawisk społecznych, jakimi są uzależnienia od substancji psychoaktywnych i samobójstwa. W przypadku samobójstw uwzględniono najbardziej wrażliwą na to zjawisko grupę - osoby nastoletnie (Mietzel, 2008).

Drugą grupą były następujące wskaźniki:

- PKB per capita uwzględniający parytet siły nabywczej;

- DN percapita;

- HDI;

- HPI. 
Dobierając wskaźniki do analizy kierowano się ich zróżnicowaniem (dwa wskaźniki tradycyjne, dwa wskaźniki alternatywne) oraz częstotliwością pojawiania się danego wskaźnika $\mathrm{w}$ debacie publicznej i dyskursie naukowym, na podstawie przeglądu podręczników akademickich i statystyk ilości wyszukiwań Google trends.

Dokonując analizy korelacji, koniecznym wydaje się uwzględnienie faktu, że wskaźnik korelacji liniowej Pearsona posiada pewne mankamenty (Sobczyk, 2007). Jednym $z$ nich jest „liniowość." Współczynnik ten świadczy jedynie o zależności liniowej, aby dowieść istnienia zależności bardziej złożonej, trzeba dokonać odpowiednich przekształceń matematycznych. Następną wadą jest fakt, że korelacja nie wyróżnia zmiennej zależnej i niezależnej. $Z$ tego powodu, na podstawie literatury przedmiotu, przyjęto na potrzeby niniejszej analizy założenie, że szczęcie zależy od dobrobytu (w literaturze występuje także podejście odwrotne) (Czapiński, 2012). Należy także uwzględnić wrażliwość współczynnika na obserwacje skrajne.

\section{Wyniki badania}

Wyniki estymacji poziomu wskaźnika korelacji liniowej Pearsona przedstawiono $\mathrm{w}$ tabeli 2. Na ich podstawie można wskazać silną, dodatnią korelację między całkowitą satysfakcją z życia a PKB per capita, DN per capita i HDI (powyżej 0,7). W przypadku tych trzech wskaźników, odnotowano także zbliżoną siłę i kierunek korelacji $z$ oceną wartości życia (rozstęp 0,08) i oceną stanu własnego zdrowia (rozstęp 0,06). Nie wystąpiła jednak istotna statystycznie korelacja między tymi trzema wskaźnikami a odsetkiem samobójstw wśród nastolatków i liczbą chorób wywołanych przez używki.

Odmienne wyniki otrzymano w przypadku wskaźnika HPI. Odnotowano słabą korelację ze wszystkimi analizowanymi indykatorami stopy życiowej i wybranych zjawisk społecznych. Najsilniejszy, lecz ciągle na śred- nim poziomie, związek wystąpił w przypadku oceny stanu zdrowia.

\section{Zakończenie}

Pomiar dobrobytu to skomplikowany i złożony proces wymagający nie tylko podejścia ekonomicznego, wykorzystującego klasyczne miary rachunku narodowego, lecz również ujęcia uwzględniającego czynniki społeczne. Biorąc pod uwagę naturę ludzką, poziom szczęścia może być niemożliwy do wiarygodnego oszacowania, $z$ uwagi na zmienność nastrojów czy niejednolitość samej definicji. Jak wskazano, powstają alternatywne wskaźniki kładące nacisk na indywidualne podejście do analizy poziomu dobrobytu. Jednak otrzymane wyniki wskazują, że w większości analizowanych przypadków, wystąpiła korelacja o średniej sile. Wyjątek stanowiła ocena satysfakcji z życia, w przypadku której odnotowano silną korelację ze wszystkimi wskaźnikami, oprócz HPI.

Mimo licznych koncepcji oceny poziomu dobrobytu i jakości życia społeczeństw, dotychczas nie udało się sformułować jednego, uniwersalnego miernika $\mathrm{w}$ tym przedmiocie. Dalsze badania powinny skupiać się na analizie składowych danego wskaźnika stopy życiowej i na identyfikacji najmocniej wpływających faktorów szczęścia.

\section{Bibliografia}

Arystoteles. (2007). Etyka Nikomachejska. Warszawa: PWN.

Barro, R.J. (1997). Makroekonomia. Warszawa: PWE.

Cieślik, E. (2008). Wybrane alternatywne sposoby mierzenia poziomu rozwoju gospodarczego. Equilibrium. Quarterly Journal of Economics and Economic Policy, 1(1-2). doi:10.12775/ EQUIL.2008.010.

Cobb, C., Halstead, T., i Rowe, J. (1995). If the GDP is up, why is America down? Atlantic Monthly.

Czapiński, J. (2012). Ekonomia szczęścia i psychologia bogactwa. Nauka, 1.

Czapiński, J. (red.). (2005). Psychologia pozytywna: nauka o szczęściu, zdrowiu, sile i cnotach cztowieka. Warszawa: PWN. 
Easterlin, R.A. (1974). Does economic growth improve the human lot? Some empirical evidence. W: P.A. David, i M.W. Reder (red.), Nations and households in economic growth: essays in honor of Moses Abramovitz. New York : Academic Press.

Easterlin, R.A. (1995). Will raising the incomes of all increase the happiness of all. Journal of Economic Behavior and Organization, 27(1). doi:10.1016/0167-2681(95)00003-B.

Eurostat. (2019). Pobrane 12.06.2019 z https:// ec.europa.eu.

Gallup Analytics. (2018). Gallup global emotions report. Pobrane 12.06.2019 z https://www.gallup. com.

Kahneman, D. i, Sugden, R. (2005). Experienced utility as a standard of policy evaluation. Environmental \& Resource Economics, 32(1). doi:10.1007/s10640-005-6032-4.

Kahneman, D., i Deaton, A. (2010). High income improves evaluation of life but not emotional well-being. Proceedings of the National Academy of Sciences, 107(38). doi:10.1073/ pnas.1011492107.

Kanasz, T. (2015). Uwarunkowania szczęścia: socjologiczna analiza wyobrażeń młodzieży akademickiej o szczęściu i udanym życiu. Warszawa: Akademia Pedagogiki Specjalnej.

Krugman, P. i Wells, R. (2012). Makroekonomia. Warszawa: PWN.

Layard, R. (2003). Happiness: has social science a clue? Lecture 1: what is happiness? Are we getting happier? Pobrane 12.06.2019 z http://eprints.lse. ac.uk.

Michoń, P. (2010). Ekonomia szczęścia. Poznań: Dom Wydawniczy Harasimowicz.

Mietzel, G. (2008). Wprowadzenie do psychologii. Gdańsk: Gdańskie Wydawnictwo Psychologiczne.

Milewski, R. i Kwiatkowski, E. (red.). (2005). Podstawy ekonomii. Warszawa: PWN.

Nordhaus, W.D. i Tobin, J. (1972). Is Growth Obsolete? W: W.D. Nordhaus, i J. Tobin, Economic research: retrospect and prospect: economic growth. New York: National Bureau of Economic Research.

OECD. (2019). Pobrane 12.06.2019 z https://data. oecd.org.

Rekowski, M. (2015). Mikroekonomia. Poznań: Contact.
Sacks, D., Stevenson, B., i Wolfers, J. (2010). Subjective well-being, income, economic development and growth. NBER Working Paper Series, 16441. doi:10.3386/w16441.

Smith, A. (2015). Badania nad natura i przyczynami bogactwa narodów, tom 1. Warszawa: PWN.

Sobczyk, M. (2007). Statystyka. Warszawa: PWN.

Stiglitz, J.E., Sen, A., i Fitoussi, J.P. (2009). Report by the Commission on the measurement of economic performance and social progress. Pobrane 12.06.2019 z https://ec.europa.eu.

Tatarkiewicz, W. (2008). O szczęściu. Warszawa: PWN.

Veenhoven, R. (2005). Happiness in hardship. W: L. Bruni, i Porta, P.L., Economics and happiness: framing the analysis. Oxford: Oxford University Press. doi:10.1093/0199286280.001.0001.

WHO. (2019). Pobrane 12.06.2019 z https://www. who.int.

Włodarczyk, K. (2014). Ekonomia wobec poczucia szczęścia. Ruch Prawniczy, Ekonomiczny i Socjologiczny, 4.

World Bank. (2019). Pobrane 12.06.2019 z https:// data.worldbank.org.

Informacje uzupełniające

Wkład autorski: autorzy zaakceptowali ostateczną wersję artykułu. Ich wkład $\mathrm{w}$ powstanie artykułu jest następujący: A.W. opracował koncepcję i plan artykułu, A.W. zebrał dane, K.K. przeanalizowat i zinterpretował dane, K.K. przygotował szkic artykułu, A.W. krytycznie zrewidował artykuł pod kątem istotnej zawartości intelektualnej.

Źródła finansowania: artykuł został sfinansowany w całości ze środków Uniwersytetu Ekonomicznego w Poznaniu.

Podziękowania autorskie: autorzy składają podziękowania za pomoc w przygotowaniu artykułu następującym osobom i instytucjom: dr Sławomir Kuźmar oraz Zarząd SKN Pecunia Moderna.

Uwagi: wyniki badania byly zaprezentowane w formie abstraktu na 9. Ogólnopolskiej Konferencji Naukowej Problemy gospodarki światowej (10 maja 2019, Toruń). 
Aneks

Tabela 1.

Determinanty szczęścia według różnych podejść w ekonomii szczęścia

\begin{tabular}{|c|c|}
\hline Autor & Determinanty szczęścia \\
\hline Easterlin (1974) & $\begin{array}{c}\text { czynniki zależne od jednostki bezpośrednio (wykształcenie, relacje, otoczenie etc.) i czyn- } \\
\text { niki pośrednie (kultura narodu, polityka państwa) }\end{array}$ \\
\hline Layard (2003) & $\begin{array}{c}\text { poczucie szczęścia zależy od wyniku porównania do innych jednostek, jego osiągnięć } \\
\text { i warunków materialnych i niematerialnych }\end{array}$ \\
\hline Veenhoven (2005) & $\begin{array}{c}\text { determinanty szczęścia traktowane są jako pięć mierników: subiektywne odczucie (ocena } \\
\text { jednostki), długowiecznośc, dochód narodowy brutto, środowisko naturalne, najbliższe } \\
\text { otoczenie }\end{array}$ \\
\hline Sacks i in. (2010). & $\begin{array}{l}\text { zamożność jako istotny determinant szczęścia, przeciętnie satysfakcja wyższa w pań- } \\
\text { stwach bogatszych }\end{array}$ \\
\hline Kahneman i Deaton (2010) & $\begin{array}{c}\text { nie istnieje algorytm szczęścia i pieniądza, szczęście można kupić, ale niecelowe jest } \\
\text { porównywanie cen w przypadku różnych jednostek }\end{array}$ \\
\hline
\end{tabular}

Źródło: Włodarczyk (2014).

Tabela 2 .

Wskaźnik korelacji liniowej Pearsona dla wybranych indykatorów stopy życiowej i wybranych zjawisk społecznych

\begin{tabular}{lccccc}
\hline Wskaźnik & $\begin{array}{c}\text { Całkowita } \\
\text { satysfakcja żzycia }\end{array}$ & $\begin{array}{c}\text { Ocena } \\
\text { wartości życia }\end{array}$ & $\begin{array}{c}\text { Samobójstwa } \\
\text { wśród nastolatków }\end{array}$ & $\begin{array}{c}\text { Ocena stanu } \\
\text { własnego zdrowia }\end{array}$ & $\begin{array}{c}\text { Choroby wywołane } \\
\text { alkoholem i narkotykami }\end{array}$ \\
\hline PKB percapita & 0,73 & 0,56 & $-0,25$ & 0,47 & $-0,17$ \\
DN per capita & 0,81 & 0,64 & $-0,14$ & 0,53 & $-0,07$ \\
HDI & 0,77 & 0,58 & $-0,10$ & 0,50 & $-0,07$ \\
HPI & 0,35 & 0,23 & $-0,35$ & 0,53 & $-0,37$ \\
\hline
\end{tabular}

Uwagi:

Dane dotyczące odsetka samobójstw wśród nastolatków pochodzą z 2015 roku.

Źródło: Opracowanie własne na podstawie danych z Eurostat (2019), OECD (2019), WHO (2019), World Bank (2019).

Schemat 1.

Podział mierników ekonomicznych

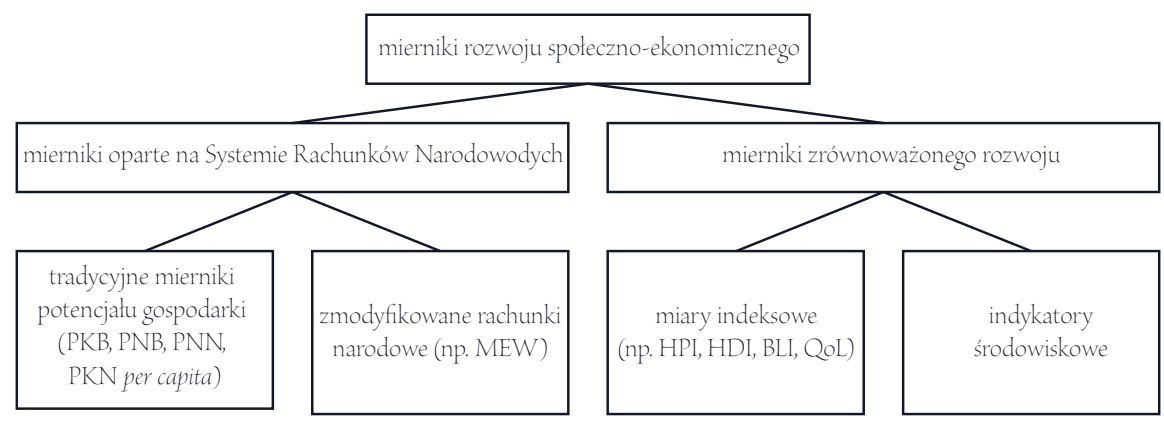

Źródło: Cieślik (2008). 
Social welfare in light of the economy of happiness based on selected European Union countries

\begin{abstract}
Motivation: One of the basic problem in macroeconomics is issue of wealth of nations. In the past, a significant part of economists, used to identify the scale of economy, or dynamics of its growth, with the life rate. Nowadays, the evaluation of wealth of a society comes down to the rating the quality of life in a given country. In the mainstream of macroeconomics discourse, Gross Domestic Product (GDP), alongside with its derivatives, is used as a key method of measurement. Unfortunately, those indicators do not include a number of key aspects, that influence the wealth ratio. Because of that, throughout the years a new, expanded approach and new indicators were developed, for example the Human Development Index (HDI). It seems essential to consider their cognitive value in the context of a modern approach to the economy of happiness. For this purpose, an overview of the most popular wealth and quality of life indicators was compiled, and was confronted with non-economic data considering the processes happening in societies, with a main focus being the interpretational disparities, and possible different outcomes.
\end{abstract}

Aim: The aim of the article is the evaluation of quality of life rate by overviewing available solutions and methods, and confrontation of the result with public statistic data considering the selected countries of the European Union (EU). Materials and methods: The systematic review and critical analysis of sources, aggregated macroeconomics data analysis and public statistics were used. Data published by Eurostat, Organisation for Economic Co-operation and Development (OECD), World Health Organization (WHO) and the World Bank were considered empirical material. Results: There are significant differences in the evaluation of life quality between the indicators used in the main economics discourse and the empirical data from other studies i.e. social and medical.

Keywords: wealth; happiness; contentment; macroeconomics JEL: E19; F59; B52 
